\title{
Underutilized wild edible plants in the Chilga District, northwestern Ethiopia: focus on wild woody plants
}

\author{
Mekuanent Tebkew ${ }^{1 *}$, Zebene Asfaw² and Solomon Zewudie ${ }^{3}$
}

\begin{abstract}
Background: Ethiopia encompasses an extraordinary number of ecological zones and plant diversity. However, the diversity of plants is highly threatened due to lack of institutional capacity, population pressure, land degradation and deforestation. An adequate documentation of these plants also has not been conducted. The farmers in Ethiopia face serious and growing food insecurity caused by drought, land degradation and climate change. Thus, rural communities are dependent on underutilized wild edible plants to meet their food and nutritional needs. Hence, this study was conducted to examine the distribution, diversity, role, management condition and associated traditional knowledge of underutilized wild edible plants with a focus on woody plants in the Chilga District, northwestern Ethiopia.

Methods: A questionnaire survey, semi-structured interviews, preference and direct matrix rankings, a market survey and focused group discussion methods were employed for data collection. Data were collected from 96 respondents. A plant inventory was also conducted on 144 quadrates in two agroecologies and in three uses. Both quantitative and qualitative data analysis methods were used. Statistical Analysis System (SAS) version 9.0 was used for statistical analysis. Analysis of Variance $(P<0.05)$ was used to compare diversity indices and species richness between agroecologies and among kebeles.

Results: Thirty-three underutilized wild edible plants were recorded in the study area. Of the recorded plants, 45\% were trees. Fruits $(76 \%)$ were the most frequently used plant parts. More than half of the respondents (56.3\% in the midland and $66.7 \%$ in the lowland area) consumed underutilized wild edible plants for supplementing staple food. Underutilized wild edible plant citation of the poor was significantly higher $(P<0.05)$ than medium and rich classes. Underutilized wild edible plants in the study area were threatened by agricultural expansion, overharvesting for fuel wood and construction, and by overgrazing. However, these plants have been given minimum conservation attention.

Conclusions: Thirty-three underutilized wild edible plants were recorded in the study area. The community consumes underutilized wild edible plants for supplementing staple food, filling food gaps and for recreation. The local community applies only some management practices to some wild edible plants. Therefore, special management is needed to sustain the benefits of these plants.
\end{abstract}

Keywords: farmlands, herbaceous species, natural forest, riverine forests, woody species

\footnotetext{
* Correspondence: mekuannttebkew@yahoo.com

${ }^{1}$ Department of Natural Resource Management, University of Gondar,

P.O. Box 196, Gondar, Ethiopia

Full list of author information is available at the end of the article
} 


\section{Introduction}

Nearly 40,000 to 100,000 plant species have been regularly used for food, shelter and medicines in the world [1]. However, only a small number of plants are widely used. The remaining plant diversity is underutilized $[1,2]$. Underutilized plants contribute immensely to family food security and serve as means of survival during times of drought, famine, shocks and risks [3]. They can also supplement nutritional requirements due to their better nutritional value $[4,5]$.

Ethiopia encompasses an extraordinary number of ecological zones [6] and plant flora [3,7-9]. Currently, however, the biodiversity of Ethiopia faces various threats. The main threats are government institutional capacity, population growth, land degradation, deforestation and weak management $[6,10]$. Similarly, in the northwestern region of Ethiopia, which is endowed with sub-humid, dry and lowland areas, plenty of wild and semi-wild edible plants are present. However, the diversity of underutilized wild edible woody plants is not well known.

The lives of farmers in Ethiopia face several challenges including deforestation, drought, land degradation, and climate change [11], all of which contribute to serious food insecurity among households [12]. Thus, in most cases, rural communities depend on underutilized edible plants [13] due to their easily accessibility [5]. Understanding underutilized wild edible woody plants (UWEP) along with their threats forms a base for local decisionmaking and helps with the application of appropriate management. In addition, it assists us with the selection of a species that can adapt in different land use systems. Nevertheless, little documentation has been conducted in Ethiopia (that is, only 5\% of Ethiopian districts have been studied) [13]. Moreover, information is lacking on the ecological distribution and potential of UWEPs for agroforestry practices and for maintaining food security in other districts of Ethiopia including the Chilga district.

The term 'underutilized wild edible plants' in this study refers to all wild edible plants (a) that are locally abundant, but globally rare; (b) that are undervalued, that is, their current public and private value is below its potential; and (c) for which there is a lack of research and information. Therefore, this study will (1) identify the distribution and quantify the diversity of UWEPs in different land uses, kebeles and agroecologies; (2) determine the role of UWEPs in livelihood diversification; (3) document the knowledge associated with utilization and management of UWEPs; and (4) identify the factors that threaten future uses and conservations of UWEPs in the Chilga District.

\section{Materials and methods Site description}

The study was conducted in the Chilga district, North Gondar Zone of the Amhara Regional State. The Chilga
District is located $12^{\circ} 55^{\prime \prime} \mathrm{N}$ and $37^{\circ} 06^{\prime \prime} \mathrm{E}$ (Figure 1). It comprises 43 administrative kebeles (KA), which are the lowest administrative units next to districts. The altitude of the district ranges from 900 to 2,267 meters above sea level (m.a.s.l.) There are two agroecologies: midland (1,500 to 2,267 m.a.s.l) and lowland (900 to 1,500 m.a.s.l). About 33\% of the area in the district is midland, while $67 \%$ is lowland agroecology. There are rivers and streams traversing the district, and these often serve as sources of water for the population (CDOA, 2012). The major soil covers of the Chilga district are 45\% Cambisols, $40 \%$ Vertisols, and 15\% Nitosols [14]. The natural vegetation of Chilga is mainly composed of various lowland and midland species [14]. The temperature of the district ranges from 11 to $32^{\circ} \mathrm{C}$ with a mean annual rainfall between 995 to $1,175 \mathrm{~mm}$. It had a total population of 241,712 and a total area of $3,181 \mathrm{~km}^{2}$. The livelihood of the local people mainly based on subsistence mixed agriculture (crop-livestock production).

\section{Selection of study sites}

The study was conducted in four kebeles of the Chilga District from 8 October to 20 December 2012. District and kebele experts were contacted for general information. In addition, secondary archived materials were reviewed from CDOA to get further information.

The district contains midland and lowland agroecologies that are classified based on altitude, annual rainfall and temperature differences. Moreover, the sociodemographic and biophysical characteristics of the two agroecologies are not the same. Thus, based on accessibility for data collection and availability of UWEPs, two KAs from each agroecology and two villages from each KA were selected (see Table 1).

\section{Selection of key informants and households}

For this study, key informants (KI) are defined as knowledgeable persons about underutilized wild edible woody plants and local conditions. After selecting two villages at each KA, 24 KI (three from each village) were selected by using a snowball method to collect preliminary data and for questionnaire development following the method of Bernard [15]. Three farmers were randomly asked to call five knowledgeable persons in the village. Then, the three most knowledgeable KI were selected out of fifteen $\mathrm{KI}$ in each village with a total of $24 \mathrm{KI}$ being selected from the study villages. Then, semi-structured interviews and questionnaires were prepared to interview the KI and household $(\mathrm{HH})$, respectively. A simple stratification of $\mathrm{HHs}$ was conducted by age $(\leq 40$ and $>40)$ and wealth (poor, medium and rich), which were commonly used in assessing the local knowledge and plant utilization [16]. Hence, $12 \mathrm{HH}$ classified by age category ( $\leq 40$ and $>40$ in 1:1 ratio) and wealth (4 $\mathrm{HH}$ for each wealth class) were taken in 


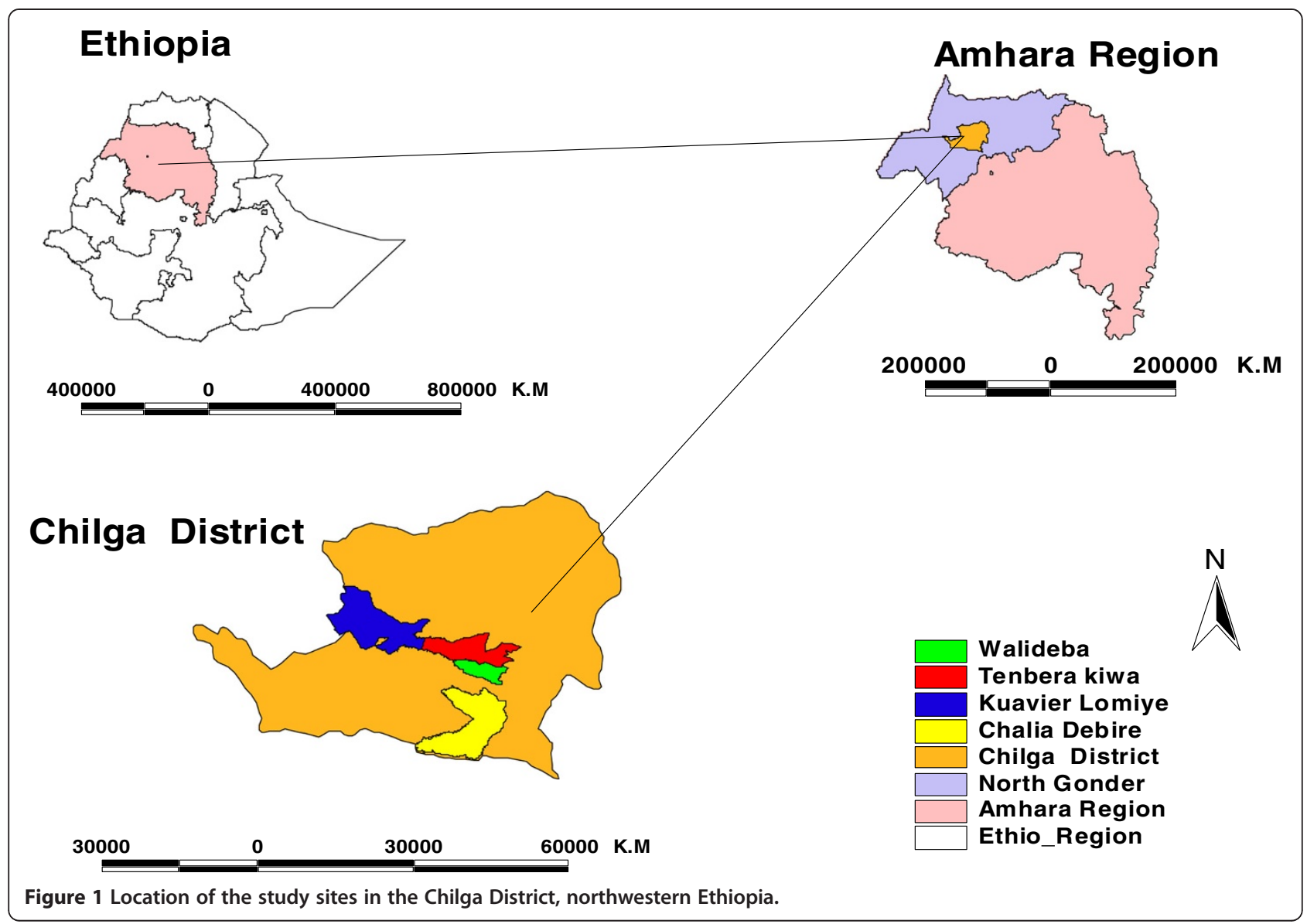

each study village (Table 2). Thus, 96 HHs (78 males and 18 females) from four KA (24 HHs from each) were interviewed for the whole study, thereby constituting $5 \%$ of the population.

\section{Data collection}

Questionnaire survey and key informant interview

Questionnaires and semistructured interviews were prepared, pretested and administered to $\mathrm{HHs}$ and KIs,

Table 1 Sampled kebeles, villages, households and altitude in the Chilga District, northwestern Ethiopia

\begin{tabular}{llll}
\hline Study kebeles & $\begin{array}{l}\text { Sampled } \\
\text { villages }\end{array}$ & $\begin{array}{l}\text { Number of } \\
\text { respondents }\end{array}$ & $\begin{array}{l}\text { Altitude } \\
\text { (m.a.s.I.) }\end{array}$ \\
\hline Quavier Lomiye $(\mathrm{N}=24)$ & Achera & 12 & Below 1,500 \\
& Bele Wuha & 12 & \\
Tenbera Kiwa $(\mathrm{N}=24)$ & Gint & 12 & Below 1,500 \\
& Kilel & 12 & \\
Walideba $(\mathrm{N}=24)$ & Bete Skangie & 12 & Above 1,500 \\
& Mehalgie & 12 & \\
Chalia Debire $(\mathrm{N}=24)$ & Ateraho & 12 & Above 1,500 \\
& Awugiber & 12 & \\
\hline
\end{tabular}

respectively $(16,17)$. All interviewees were met on a 'one-to-one' basis and asked the same standard (openand closed-ended) questions using the local language (Amharic) based on their consent, including expansions or clarifications as needed. Consent was given by the informants to the district agricultural office. Information including vernacular names, parts used and consumption role of the plants was gathered. In addition, traditional management practices, other uses, and threats of UWEPs were also recorded.

\section{Field observation and focused group discussion}

Repeated field observations were conducted in the study sites by walking transects where most of the UWEPs are grown/cultivated. The purpose of the field observation was to obtain actual information of presence, growth habit, habitat characteristics and identification of edible plant species mentioned during the interviews. A focused group discussion of KI was conducted at each study site to verify the data and identification of underutilized edible plants. All underutilized wild edible plants listed in the socioeconomic survey were verified and idiosyncratic ideas were removed from the data. 
Table 2 Importance value index (IVI) of the top ten woody species in three land uses and two agroecologies in Chilga District, northwestern Ethiopia

\begin{tabular}{|c|c|c|c|c|c|c|c|}
\hline \multirow[b]{2}{*}{ Scientific name } & \multicolumn{3}{|l|}{ LLA } & \multicolumn{3}{|l|}{ MLA } & \multirow[b]{2}{*}{ Average } \\
\hline & $\overline{\mathrm{NF}}$ & $\mathbf{R}$ & $\mathrm{FL}$ & $\overline{\mathrm{NF}}$ & $\mathbf{R}$ & $\mathrm{FL}$ & \\
\hline Anogeissus leiocarrpa & $39.88^{b}$ & $39.51^{b}$ & 17.25 & $32.80^{a}$ & $16.66^{c}$ & 13.68 & $26.63^{a}$ \\
\hline Syzygium guineense & - & 0.95 & - & $28.72^{b}$ & $86.63^{a}$ & $32.99^{c}$ & $24.88^{b}$ \\
\hline Focus sycomorus & 22.73 & 8.19 & 15.01 & 7.92 & 7.72 & $42.22^{b}$ & 17.30 \\
\hline Diospyros abyssinica & 3.22 & $80.93^{a}$ & 8.81 & 2.11 & 8.41 & 1.07 & 17.31 \\
\hline Flueggea virosa & $35.80^{c}$ & 12.85 & $32.31^{b}$ & 3.74 & - & 1.03 & 14.29 \\
\hline Terminalia laxiflora & $42.26^{a}$ & 1.77 & $25.94^{c}$ & 8.71 & 1.77 & 5.10 & 13.96 \\
\hline Croton macrostachus & - & - & 4.91 & $18.00^{c}$ & 11.13 & $47.83^{a}$ & 13.64 \\
\hline Maytenus arbutifolia & 2.28 & 13.27 & 1.41 & 14.48 & $23.94^{b}$ & 25.86 & 13.54 \\
\hline Acacia polyachanta & 21.56 & 15.31 & $39.45^{a}$ & - & - & - & 12.72 \\
\hline Acalypha sp. & 1.51 & $21.84^{c}$ & - & 13.06 & 3.83 & 3.19 & 7.24 \\
\hline Others & 130.76 & 105.38 & 154.91 & 170.46 & 139.91 & 127.03 & 138.49 \\
\hline
\end{tabular}

LLA, lowland agroecology; MLA, midland agroecology; NF, natural forest; $\mathrm{R}$, riverine forest; $\mathrm{FL}$, farmland; Bold numbers with superscripts of a, $b$ and $\mathrm{c}$ in each column are top three IVI values from highest to lowest order.

\section{Direct matrix ranking}

Direct matrix ranking was used to compare selected multipurpose species based on service categories. A direct matrix ranking method was exercised for commonly reported multipurpose UWEPs to assess their relative importance to local people and the extent of the existing threats related to their use values following the method of $[16,17]$. Six KI from each agroecology were selected and asked to assign a use value ( 5 to 0 ) for seven species in the lowland agroecology and for five species in the midland agroecology. The frequency of citation as multipurpose species was used for ranking UWEPs. Use categories for the comparison included construction, medicine, fruit/food, fuel wood, shade, farm and household implements, and fences, as used in the work of Cotton (16) and Martin (17).

\section{Preference ranking}

Preference ranking of selected UWEPs was conducted using taste and use criteria for each study kebele to assess the perception of the community. The most preferred underutilized wild edible plants in each study kebele were selected by KIs, and ranking (4-most preferred, 3-commonly preferred, 2-preferred but not so common, and 1-occasionally used) was conducted by all respondents, who followed the method of Jain et al. [17]. Similarly ranking of conservation demand for selected underutilized wild edible plants was conducted to assess conservation status of most preferred species following the method of Jain et al. [18] (4-for the species whose conservation is highly demanded, 3-conservation urgently demanded, 2-conservation required but not so urgent, and 1-conservation not required at present). Finally, such ranking of the species was summed up, and average ranking was employed at the site level.

\section{Threats to underutilized edible}

The major human and natural factors that possibly threaten the survival of underutilized wild edible plants were identified through preliminary assessment. Thus, based on the relative importance of the threatening factors, priority ranking was conducted by eight KIs using the method of [16]. One to five scores were assigned where one was for the least while five was for the most destructive threat. Then, all ranks were summed up, and total ranking was conducted to determine the main threats.

\section{Market survey}

Assessments of Gint, Negadie Bahire, and Chandeba local markets (nearest market places to the study sites) were conducted to judge market prices of the recorded underutilized edible plants.

\section{Plant identification}

All encountered plants were identified and recorded by their vernacular names. Later, these were converted to their botanical names using Flora of Ethiopia and Eritrea [19-25] and experience. Plant specimens were collected and taken to the National Herbarium of Addis Ababa University for plant identification of plants that were not identified in the field.

Vegetation inventory Field inventory of all UWEPS (woody) was employed with key informants to obtain information on the type of plants and their species diversity. 
To conduct this, the selected study villages were stratified into three land uses (forms), that is, (1) natural forest (NF), (2) farmland (FL), and (3) riverine forests (R). Then, representative populations in each land use/form were selected. Six quadrates were laid in each land use per village following two transects running parallel along the gradient. The two transect lines were $200 \mathrm{~m}$ apart and quadrates along the transect lines were also $200 \mathrm{~m}$ apart both in the natural forest and farmland. For riverine areas, two transect lines were established for each village following the water flow and three quadrate were taken at 200-m intervals from each transect line. The first quadrate

Table 3 List of all underutilized edible plants encountered in the Chilga District, northwestern Ethiopia

\begin{tabular}{|c|c|c|c|c|c|c|c|}
\hline Scientific name (Family) & $\begin{array}{l}\text { Vernacular } \\
\text { name (Amh) }\end{array}$ & Habit & Habitat & Added values & PU & MD & $\begin{array}{l}\text { Voucher } \\
\text { number }\end{array}$ \\
\hline Acanthus sennii Chiov. (Acanthaceae) & Kushashile & $\mathrm{SH}$ & $\mathrm{BN}, \mathrm{N}, \mathrm{R}$ & $\mathrm{FE}, \mathrm{FU}$, & $\mathrm{FL}$ & $\mathrm{F}$ & MT-001 \\
\hline Balanites aegyptiaca (L.) . (Balanitaceae) & Kudekuda & $\mathrm{T}$ & $N, R, F$ & $\mathrm{FE}, \mathrm{FU}, \mathrm{SC}$ & $\mathrm{F}$ & $\mathrm{F}$ & MT-002 \\
\hline Boletus edulis Bull. Ex Fries. (Bolentaceae) & Enguday & $\mathrm{H}$ & $\mathrm{F}, \mathrm{N}$ & - & ST & $P$ & MT-003 \\
\hline Carissa Spinarum L. (Apocynaceae) & Agam & $\mathrm{SH}$ & $N, R$ & $F E, M, F U, F T$ & $\mathrm{~F}$ & $\mathrm{~F}$ & MT-004 \\
\hline Corchorus olitorius L. (Tiliaceae) & Kudra & $\mathrm{H}$ & $\mathrm{F}$ & FD, Rope & L & $P$ & MT-005 \\
\hline Cordia africana L. (Boraginaceae) & Wanza & $\mathrm{T}$ & $\mathrm{H}$ & $\mathrm{T}, \mathrm{FU}, \mathrm{FE}, \mathrm{FU}, \mathrm{SH}, \mathrm{FD}, \mathrm{M}$ & $\mathrm{F}$ & $\mathrm{F}$ & MT-006 \\
\hline Dichrostachys cinerea Wight \& Am (Fabaceae) & andera & $\mathrm{S} / \mathrm{T}$ & N & - & $\mathrm{F}$ & $\mathrm{F}$ & MT-007 \\
\hline Dioscorea prahensilis Benth (Dioscoreaceae) & Senssa & C & $N, R$ & - & $\mathrm{R}$ & $P$ & MT-008 \\
\hline Diospyros abyssinica (Hiem) F. Wite (Ebenaceae) & Serkin & $\mathrm{T}$ & $F, R$ & $\mathrm{FU}, \mathrm{T}, \mathrm{CO}, \mathrm{SH}, \mathrm{FE}$ & $\mathrm{F}$ & $\mathrm{F}$ & MT-009 \\
\hline Diospyros mesiliformis Hochst ex.A.DC. (Ebenaceae) & Gurmacha & $\mathrm{T}$ & $F, R$ & $\mathrm{~T}, \mathrm{FU}, \mathrm{SH}, \mathrm{CO}, \mathrm{FE}, \mathrm{SC}$ & $\mathrm{F}$ & $\mathrm{F}$ & MT-010 \\
\hline Dovyalis abyssinica (A. Rich.) Warburg. (Flacourtiaceae) & Koshim & $\mathrm{T}$ & $N, R$ & $\mathrm{FU}, \mathrm{FE}$ & $\mathrm{F}$ & $\mathrm{F}$ & MT-011 \\
\hline Ficus sur Forssk. (Moraceae) & Shola & $\mathrm{T}$ & $R, F, N$ & $\mathrm{CO}, \mathrm{FE}, \mathrm{SC}, \mathrm{SH}, \mathrm{FU}$ & $\mathrm{F}$ & $\mathrm{F}$ & MT-012 \\
\hline Ficus sycomorus L. (Moraceae) & Bamba & $\mathrm{T}$ & $\mathrm{F}, \mathrm{N}, \mathrm{R}, \mathrm{H}$ & $\mathrm{CO}, \mathrm{FE}, \mathrm{SC}, \mathrm{FD}, \mathrm{SH}, \mathrm{HB}$ & $\mathrm{F}$ & $\mathrm{F}$ & MT-013 \\
\hline Ficus vallis-choudae Del. (Moraceae) & Bambula & $\mathrm{T}$ & N & $F U, F E$ & $\mathrm{~F}$ & $\mathrm{~F}$ & MT-014 \\
\hline Ficus vasta Forssk. (Moraceae) & Warka & $\mathrm{T}$ & $\mathrm{N}, \mathrm{R}, \mathrm{F}, \mathrm{H}$ & $\mathrm{FU}, \mathrm{CO}, \mathrm{FE}, \mathrm{SC}$ & $\mathrm{F}$ & $\mathrm{F}$ & MT-015 \\
\hline Flueggea virosa Guill. \& Perr. (Euphorbiaceae) & Shasha & $\mathrm{SH}$ & $F, N, R$ & $\mathrm{FE}, \mathrm{FU}, \mathrm{CO}, \mathrm{FU}$ & $\mathrm{F}$ & $\mathrm{F}$ & MT-016 \\
\hline Gardenia ternifolia Schumach and Thonn. (Rubiaceae) & Gambilo & $\mathrm{S} / \mathrm{T}$ & $F, N, R$ & $F D, F U$, & $\mathrm{F}$ & $\mathrm{F}$ & MT-017 \\
\hline Gloriosa superba (Liliaceae) & Yemariam twa & $\mathrm{H} / \mathrm{sh}$ & $\mathrm{F}$ & FD, WASHING & $\mathrm{F}$ & $\mathrm{F}$ & MT-018 \\
\hline Hibiscus cannabinus L. (Malvaceae) & Yeberha Wayika & $\mathrm{H}$ & $\mathrm{F}$ & FD & $\mathrm{F}$ & $\mathrm{D}$ & MT-019 \\
\hline Hibiscus esculentus L. (Malvaceae) & Wayika & $\mathrm{H}$ & $\mathrm{F}$ & $\mathrm{M}, \mathrm{FD}$ & L & & MT-020 \\
\hline Maytenus senegalensis Forssk (Celastraceae) & Koshikosh & $\mathrm{T}$ & $N, F, R$ & $\mathrm{FE}, \mathrm{FT}$, & $\mathrm{F}$ & $\mathrm{F}$ & MT-021 \\
\hline Mimusops kummel Bruce ex A.DC. (Sapotaceae) & Ishe & $\mathrm{T}$ & $\mathrm{R}, \mathrm{F}$ & $\mathrm{FE}, \mathrm{FU}, \mathrm{HB}, \mathrm{CO}$, & $\mathrm{F}$ & $\mathrm{F}$ & MT-022 \\
\hline Morusmeso zygia (Moraceae) & Injori & C & $N, R$ & - & $\mathrm{F}$ & $\mathrm{F}$ & MT-023 \\
\hline Pittosporum viridiflorum Sims. (Pittosporaceae) & Dengay Seber & S & $N, F, R$ & FU & $\mathrm{F}$ & $\mathrm{F}$ & MT-024 \\
\hline $\begin{array}{l}\text { Rhus glutinosa A. Rich. subsp. Abyssinica (Oliv.) M. Gilnert } \\
\text { (Anacardiaceae) }\end{array}$ & Qamo & S & $N, R$ & $\mathrm{Fe}, \mathrm{FU}$ & $\mathrm{F}$ & $\mathrm{F}$ & MT-025 \\
\hline Rosa abyssinica Lindley (Rosaceae) & Qega & $\mathrm{SH}$ & N & $\mathrm{FE}, \mathrm{FU}$, & $\mathrm{F}$ & $\mathrm{F}$ & MT-026 \\
\hline Saba comorensis (Bo).) Pichon (Apocynaceae) & Ashama & C & $\mathrm{R}$ & $\mathrm{CO}, \mathrm{SH}$ & $\mathrm{F}$ & $\mathrm{F}$ & MT-027 \\
\hline Sporobolus africanus (Poir) Robyns and Tournay (Poaceae) & Muriye & $\mathrm{H}$ & $N, F L D, R$ & FD & S & $\mathrm{D}$ & MT-028 \\
\hline Syzygium guineense (Willd.) DC. (Myrtaceae) & Dokima & $\mathrm{T}$ & $R, F$ & $\mathrm{M}, \mathrm{FE}, \mathrm{FU}, \mathrm{SH}, \mathrm{CO}$ & $\mathrm{F}$ & $\mathrm{F}$ & MT-019 \\
\hline Tamarindus indica L. (Fabaceae) & Kumer & $\mathrm{T}$ & $\mathrm{R}, \mathrm{N}, \mathrm{F}$ & $\mathrm{FE}, \mathrm{FU}, \mathrm{CO}, \mathrm{SC}$ & S & $\mathrm{D}$ & MT-030 \\
\hline Ximenia americana L. (Olacaceae) & Enkoye & Sh & N & $\mathrm{FU}, \mathrm{M}$ & $\mathrm{F}$ & $\mathrm{F}$ & MT-031 \\
\hline Ziziphus abyssinica Hoschst. (Rhamnaceae) & Abetere & $\mathrm{T}$ & $F, N, R$ & $\mathrm{Fu}, \mathrm{Fe}$ & $\mathrm{F}$ & $\mathrm{F}$ & MT-032 \\
\hline Ziziphus spina-christi Willd. (Rhamnaceae) & Arka & $\mathrm{S} / \mathrm{T}$ & N & $\mathrm{Fe}, \mathrm{Fu}, \mathrm{co}, \mathrm{Fd}, \mathrm{sc}$ & $\mathrm{F}$ & $\mathrm{F}$ & MT-033 \\
\hline
\end{tabular}

Key to abbreviations: Habit; Sh, shrub; $\mathrm{T}$, tree; $\mathrm{H}$, herb; $\mathrm{C}$, climber; Habitat: $\mathrm{N}$, natural forest; $\mathrm{F}$, farmland; $\mathrm{R}$; riverine and valley; $\mathrm{H}$, home garden; Fld, field. BN, boundary; Added value: Fu, fuel wood; $\mathrm{CH}$, charcoal; M, medicinal; $\mathrm{CO}$, construction; Fe, fencing; SC, soil and water conservation; FD, fodder; Sh, shade; HB, production; T, timber; FT, farm and household tools. PU (Parts used): F, fruit; R, root; Fl, flower nectar; S, seed; W, whole part. Mode of utilization (MD): F, fresh; $\mathrm{P}$, prepared/cooked; D, dried and prepared. 
in each land use was laid out randomly from the east of the sampled population. The quadrate sizes for natural forest and riverine forest was $20 \mathrm{~m} \times 20 \mathrm{~m}\left(400 \mathrm{~m}^{2}\right)$ for trees (main plot), $10 \mathrm{~m} \times 10 \mathrm{~m}$ for shrubs and saplings at the center of main plot, and $1 \mathrm{~m} \times 1 \mathrm{~m}$ for herbs and seedlings with an ' $\mathrm{X}$ ' design that followed the method of $[26,27]$. For farmland, a quadrate size of $50 \mathrm{~m} \times 40 \mathrm{~m}$ (main plot) for trees, $25 \mathrm{~m} \times 20 \mathrm{~m}$ for saplings and shrubs, and five $2 \mathrm{~m} \times 2 \mathrm{~m}$ in an ' $\mathrm{X}$ ' design for seedlings and herbs was taken.

In the smallest subplots $\left(1 \mathrm{~m}^{2}\right)$ or $4 \mathrm{~m}^{2}$, all herbs and seedlings were identified and counted (including all plants less than $50 \mathrm{~cm}$ in height). In the subplots of 10 $\mathrm{m} \times 10 \mathrm{~m}$ or $25 \mathrm{~m} \times 20 \mathrm{~m}$, diameter at breast height $(\mathrm{DBH})$ of all saplings and shrubs $(\mathrm{DBH}<10 \mathrm{~cm})$ was measured with a caliper. The $\mathrm{DBH}$ of trees $(\mathrm{DBH} \geq 10$ $\mathrm{cm}$ ) were measured in the entire plot area. Trees forked below breast height were measured independently and average $\mathrm{DBH}$ was taken. One hundred forty-four main quadrates were taken for the whole study.

\section{Data analysis}

Both quantitative and qualitative data analyses were conducted after the necessary data collection. Statistical Analysis System (SAS) 9.0 version software was used for descriptive and statistical analysis. Descriptive analyses (informant consensus, direct matrix ranking and preference ranking) were presented in the form of percentages, figures and means. An analysis of variance (ANOVA) of diversity indices (Shannon Weiner diversity index, Simpson's diversity index and evenness), species richness and wealth classes was conducted to compare diversity between agroecologies and among kebeles. A T test mean separation $(P<0.05)$ of diversity indices and wealth classes was conducted using least significance difference (LSd). The Spearman Rank Correlation test was also employed to evaluate whether there is significant $(P<0.05)$ correlation between age and UWEPs list.

\section{Species richness}

It is defined as the number of species per quadrate, area or community. In this particular case, the numbers of observed species across the whole sample quadrates of each land use in each agroecology and Kebele were used as a representation of species richness. However, quadrate species richness is used as a comparison of species richness between agroecologies and kebeles.

\section{Shannon diversity index $\left(H^{\prime}\right)$}

It is very important when comparing diversity among samples and habitats to use an index that is more sensitive to richness. The value of $\mathrm{H}^{\prime}$ is usually found to fall between 1.5 and 3.5 and only rarely surpasses 4.5 [28,29].
Therefore, the species diversity of the midland and lowland agroecologies was estimated as follows:

$$
\mathrm{H}^{\prime}=-\sum_{1}^{s} P i \ln p i
$$

where $\mathrm{H}^{\prime}=$ is Shannon diversity and $\mathrm{Pi}=$ proportion of individual species.

\section{Simpson's diversity index}

Simpson's diversity index is the most widely used method for estimating the richness diversity of community and is used to compare different communities or habitats [29]. The Simpson diversity is less sensitive to richness and more sensitive to evenness. The Simpson's diversity is calculated as follows:

$$
\mathrm{D}=1-\sum_{n=1}^{s} P i^{2}
$$

\section{Evenness}

It is a widely used and understood method for estimating evenness of the communities [30]. The most commonly used index of estimating evenness diversity is the Pielou index, which is determined as follows:

$$
\mathrm{J}^{\prime}=\mathrm{H}^{\prime} / \mathrm{H}^{\prime} \max
$$

where J'= Pielou evenness index; $H^{\prime}=$ the observed value of Shannon index; H'max $=\ln S$, and $S=$ total number of species.

\section{Importance value index and relative frequency}

Estimation of the importance value index (IVI), abundance, frequency and relative frequency was conducted to assess the importance of each species to the survey sites using the method of [31] and [32] and these estimates are determined with the following:

$$
\begin{aligned}
\text { IVI }= & \text { Relative Frequency }+ \text { Relative Density } \\
& + \text { Relative Dominance }
\end{aligned}
$$

Table 4 Underutilized woody edible plants species diversity for three land uses in lowland agroecology (LLA) and midland agroecology (MLA) of the study area, northwestern Ethiopia

\begin{tabular}{lllll}
\hline Agroecology & Species richness & Simpson_1-D & Shannon & Evenness \\
\hline Lowland & & & & \\
NF & 14 & 0.69 & 1.73 & 0.66 \\
R & 14 & 0.79 & 1.93 & 0.73 \\
FL & 12 & 0.76 & 1.78 & 0.71 \\
Midland & & & & \\
NF & 12 & 0.78 & 1.77 & 0.71 \\
R & 14 & 0.79 & 2.05 & 0.78 \\
FL & 12 & 0.82 & 1.92 & 0.77 \\
\hline
\end{tabular}

$\mathrm{NF}$, natural forest; $\mathrm{R}$, riverine forest; $\mathrm{FL}$, farmland. 
Table 5 Underutilized woody edible plants species diversity for three land uses in the study sites, northwestern Ethiopia

\begin{tabular}{|c|c|c|c|c|c|c|c|c|c|c|c|c|}
\hline \multirow[t]{2}{*}{ Study sites } & \multicolumn{3}{|c|}{ Species richness } & \multicolumn{3}{|c|}{ Simpson_1-D } & \multicolumn{3}{|c|}{ Shannon_H } & \multicolumn{3}{|c|}{ Evenness } \\
\hline & $\mathrm{NF}$ & $\mathbf{R}$ & $\mathrm{FL}$ & $\mathrm{NF}$ & $\mathbf{R}$ & $\mathrm{FL}$ & $\mathrm{N}$ & $\mathbf{R}$ & $\mathrm{FL}$ & $\mathrm{NF}$ & $\mathbf{R}$ & $\mathrm{FL}$ \\
\hline Quavere Lomiye & 10 & 13 & 6 & 0.74 & 0.8 & 0.67 & 1.7 & 1.95 & 1.33 & 0.74 & 0.76 & 0.74 \\
\hline Tenbera & 12 & 7 & 11 & 0.63 & 0.73 & 0.7 & 1.55 & 1.55 & 1.67 & 0.62 & 0.8 & 0.7 \\
\hline Walideba & 12 & 13 & 10 & 0.76 & 0.88 & 0.76 & 1.78 & 2.34 & 1.72 & 0.71 & 0.91 & 0.75 \\
\hline Chalia Debire & 7 & 10 & 4 & 0.67 & 0.66 & 0.6 & 1.37 & 1.57 & 1.05 & 0.7 & 0.68 & 0.76 \\
\hline
\end{tabular}

LLA, lowland agroecology; MLA, midland agroecology; NF, natural forest; R, riverine forest; FL, farmland.

Frequency $=$ number of occurence of a given species in the plots studied

Relative Frequency $(\%)=\frac{\text { Frequency of any species }}{\text { Total frequency of all species }} * 100$

$$
\text { Relative Density }(\%)=\frac{\begin{array}{c}
\text { Number of individual of } \\
\text { each species per ha }
\end{array}}{\begin{array}{c}
\text { Total number of individuals } \\
\text { of all species per ha }
\end{array}} * 100
$$

Relative Dominance $(\%)=\frac{\text { Basal area of each species }}{\text { Total basal area of all species }} * 100$

Basal area $=\frac{\prod \mathrm{D}^{2}}{4}, \mathrm{D}=$ Diameter of trees at breast height

\section{(5) Results}

Importance value index

The importance value index (IVI) of woody species is dominated by four species (86.12\%), namely Anogeissus leiocarrpa, Syzygium guineense, Diospyros abyssinica and Ficus sycomorus (Table 2 and Additional file 1). The species distribution varies in land uses and in agroecologies. In the lowlands (LLA), Terminalia laxiflora, Diospyros abyssinica and Acacia polyachanta are the top ranking species for NF, riverine and FL, respectively. Anogeissus leiocarrpa, Syzygium guineense and Ficus sycomorus are also the first ranked species in the midland (MLA) for NF, riverine and FL land uses, respectively. Some of the woody plants in the study area were habitat specific. For example, Syzygium guineense was recorded only from riverine land use of the LLA.

\section{Diversity of underutilized wild edible plants}

Thirty-three UWEPs (28 woody and five herbaceous) species were recorded in the study area (Table 3). The family Moraceae had five species; the families Malvaceae, Fabaceae, and Euphorbiaceae had two species each; and the remaining families had one species each.

Table 6 Means ( \pm std) of woody underutilized edible plant diversity for the three land uses in the study area, northwestern Ethiopia

\begin{tabular}{lllll}
\hline Diversity indices & Agroecology & NF & R & FL \\
\hline Richness & MLA & $2.87^{\mathrm{a}} \pm 0.29$ & $3.71^{\mathrm{a}} \pm 0.38$ & $2.00^{\mathrm{a}} \pm 0.22$ \\
& LLA & $3.42^{\mathrm{a}} \pm 0.22$ & $3.17^{\mathrm{a}} \pm 0.35$ & $1.87^{\mathrm{a}} \pm 0.33$ \\
Simpson & Over all mean & $3.15 \pm 0.18$ & $3.44 \pm 0.26$ & $1.93 \pm 0.19$ \\
& MLA & $0.44^{\mathrm{a}} \pm 0.05$ & $0.55^{\mathrm{a}} \pm 0.04$ & $0.31^{\mathrm{a}} \pm 0.05$ \\
& LLA & $0.55^{\mathrm{a}} \pm 0.03$ & $0.46^{\mathrm{a}} \pm 0.06$ & $0.27^{\mathrm{a}} \pm 0.06$ \\
Shannon & Overall mean & $0.49 \pm 0.03$ & $0.51 \pm 0.03$ & $0.29 \pm 0.04$ \\
& MLA & $0.77^{\mathrm{a}} \pm 0.09$ & $1.02^{\mathrm{a}} \pm 0.09$ & $0.51^{\mathrm{a}} \pm 0.09$ \\
& LLA & $0.97^{\mathrm{a}} \pm 0.07$ & $0.85^{\mathrm{a}} \pm 0.12$ & $0.46^{\mathrm{a}} \pm 0.11$ \\
Evenness & Overall mean & $0.87 \pm 0.06$ & $0.93 \pm 0.08$ & $0.48 \pm 0.07$ \\
& MLA & $0.68^{\mathrm{b}} \pm 0.06$ & $0.80^{\mathrm{a}} \pm 0.06$ & 0.06 \\
& LLA & $0.82^{\mathrm{a}} \pm 0.03$ & $0.66^{\mathrm{a}} \pm 0.08$ & 0.08 \\
\end{tabular}

\footnotetext{
a,b Means with the same letter ordered vertically within each diversity parameter are not significant $(P<0.05)$.
}

$\mathrm{FL}$, farmland; LLA, lowland agroecology; MLA, midland agroecology; NF, natural forest; $R$, riverine forest. 
Table 7 Mean ( \pm std) of underutilized woody wild edible plant diversity for the three land uses in lowland agroecology (LLA) of the Chilga District, northwestern Ethiopia

\begin{tabular}{|c|c|c|c|c|}
\hline Diversity indices & Kebeles & NF & $\mathbf{R}$ & $\mathrm{FL}$ \\
\hline \multirow[t]{3}{*}{ Richness } & Quavere Lomiye & $3.08^{\mathrm{a}} \pm 0.31$ & $4.25^{a} \pm 0.43$ & $1.92^{\mathrm{a}} \pm 0.29$ \\
\hline & Tenbera & $3.75^{a} \pm 0.30$ & $2.08^{b} \pm 0.34$ & $1.83^{\mathrm{a}} \pm 0.61$ \\
\hline & Overall mean & $3.42 \pm 0.22$ & $3.17 \pm 0.35$ & $1.87 \pm 0.33$ \\
\hline \multirow[t]{3}{*}{ Simpson } & Quavere Lomiye & $0.52^{a} \pm 0.06$ & $0.59^{\mathrm{a}} \pm 0.06$ & $0.34^{a} \pm 0.07$ \\
\hline & Tenbera & $0.57^{\mathrm{a}} \pm 0.05$ & $0.34^{b} \pm 0.09$ & $0.19^{\mathrm{a}} \pm 0.09$ \\
\hline & Overall mean & $0.55 \pm 0.03$ & $0.46 \pm 0.06$ & $0.27 \pm 0.06$ \\
\hline \multirow[t]{3}{*}{ Shannon } & Quavere Lomiye & $0.90^{\mathrm{a}} \pm 0.10$ & $1.15^{\mathrm{a}} \pm 0.13$ & $0.53^{\mathrm{a}} \pm 0.13$ \\
\hline & Tenbera & $1.05^{a} \pm 0.09$ & $0.55^{b} \pm 0.16$ & $0.39^{a} \pm 0.18$ \\
\hline & Overall mean & $0.98 \pm 0.07$ & $0.85 \pm 0.12$ & $0.46 \pm 0.11$ \\
\hline \multirow[t]{3}{*}{ Evenness } & Quavere Lomiye & $0.83^{\mathrm{a}} \pm 0.04$ & $0.78^{\mathrm{a}} \pm 0.07$ & $0.59^{a} \pm 0.13$ \\
\hline & Tenbera & $0.82^{a} \pm 0.05$ & $0.55^{\mathrm{a}} \pm 0.14$ & $0.27^{\mathrm{a}} \pm 0.12$ \\
\hline & Overall mean & $0.82 \pm 0.03$ & $0.66 \pm 0.08$ & $0.43 \pm 0.09$ \\
\hline
\end{tabular}

$\overline{\mathrm{a}, \mathrm{b}}$ Means with the same letter ordered vertically within each diversity parameter are not significant $(P<0.05)$.

$\mathrm{FL}$, farmland; NF, natural forest; $\mathrm{R}$, riverine forest.

Species richness of underutilized wild edible woody plants (UWEPs) recorded in the study area is presented in Tables 4 and 5. Overall, mean value difference in species richness and diversity indices of UWEPs in two agroecologies were in the order of: R $>$ NF $>$ FL (Table 6). Evenness in the LLA was significantly $(P<0.05)$ higher than MLA for NF land use. Comparison of diversity within each agroecology shows species richness of riverine land use at Quavier Lomiye Kebele was significantly higher than at Tenbera in the LLA (Table 7). Within the MLA, for NF land use, Simpson and evenness diversity indices of Chalia Debire Kebele were significantly higher than Walideba Kebele Simpson and evenness diversity (Table 8).

\section{Underutilized wild edible plants habits and parts used} Growth forms of UWEPs comprise trees, shrubs, herbs and climbers. Of all $(\mathrm{n}=33)$ UWEPs, most $(45 \%)$ were trees followed by shrubs (about 27.3\%) (Figure 2a). Trees were also the dominant growth forms at each study site, representing about half at Walideba, Chalia Debire and Quabier Lomiye and $46.4 \%$ at Tenbera Kebele. The study also indicated that fruits were the most commonly

Table 8 Mean ( \pm std) of woody wild edible species diversity for three land uses in midland agroecology (MLA) in northwestern Ethiopia

\begin{tabular}{|c|c|c|c|c|}
\hline Diversity Indices & Kebele & $\mathrm{NF}$ & $\mathbf{R}$ & $\mathrm{FL}$ \\
\hline \multirow[t]{3}{*}{ Richness } & Walideba & $2.67^{a} \pm 0.56$ & $3.08^{\mathrm{a}} \pm 0.57$ & $2.33^{\mathrm{a}} \pm 0.38$ \\
\hline & Chalia Debire & $3.08^{\mathrm{a}} \pm 0.19$ & $4.33^{\mathrm{a}} \pm 0.47$ & $1.67^{\mathrm{a}} \pm 0.19$ \\
\hline & Overall mean & $2.87 \pm 0.29$ & $3.71 \pm 0.38$ & $2.00 \pm 0.22$ \\
\hline \multirow[t]{3}{*}{ Simpson } & Walideba & $0.35^{b} \pm 0.078$ & $0.52^{a} \pm 0.08$ & $0.36^{a} \pm 0.08$ \\
\hline & Chalia Debire & $0.54^{a} \pm 0.03$ & $0.58^{a} \pm 0.03$ & $0.27^{a} \pm 0.07$ \\
\hline & Overall mean & $0.44 \pm 0.05$ & $0.55 \pm 0.04$ & $0.32 \pm 0.06$ \\
\hline \multirow[t]{3}{*}{ Shannon } & Walideba & $0.64^{a} \pm 0.15$ & $0.92^{\mathrm{a}} \pm 0.17$ & $0.61^{a} \pm 0.15$ \\
\hline & Chalia Debire & $0.91^{a} \pm 0.06$ & $1.11^{\mathrm{a}} \pm 0.09$ & $0.40^{\mathrm{a}} \pm 0.11$ \\
\hline & Overall mean & $0.78 \pm 0.09$ & $1.02 \pm 0.09$ & $0.51 \pm 0.09$ \\
\hline \multirow[t]{3}{*}{ Evenness } & Walideba & $0.54^{b} \pm 0.10$ & $0.79^{a} \pm 0.12$ & $0.59^{\mathrm{a}} \pm 0.13$ \\
\hline & Chalia Debire & $0.83^{a} \pm 0.04$ & $0.82^{a} \pm 0.04$ & $0.53^{\mathrm{a}} \pm 0.14$ \\
\hline & Overall mean & $0.68 \pm 0.06$ & $0.80 \pm 0.06$ & $0.56 \pm 0.09$ \\
\hline
\end{tabular}

$\overline{a, b}$ Means with the same letter ordered vertically within each diversity parameter are not significant $(P<0.05)$.

$\mathrm{NF}$, natural forest; $\mathrm{R}$, riverine forest; $\mathrm{FL}$, farmland. 

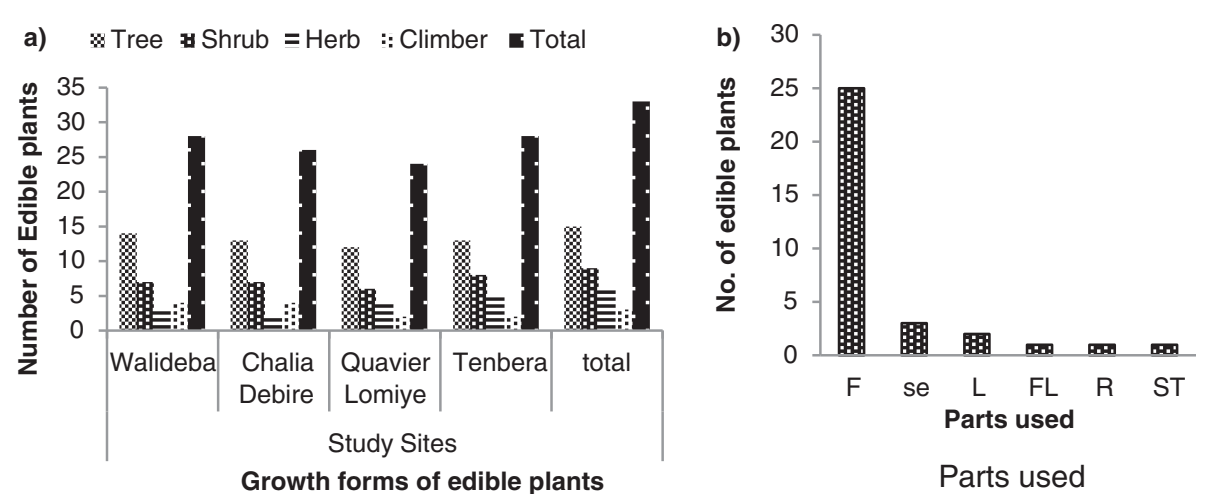

Figure 2 Growth forms and parts used for edible plants in the study area, northwestern Ethiopia. F, fruit; Se, seed; L, leaf; Fl, flower nectar; $R$, root/ tuber; $S T$, stem bark.

used parts of UWEPs (76\%), while flowers, roots, and stems were the least used parts (Figure $2 \mathrm{~b}$ ).

\section{Utilization and role of underutilized wild edible plants} The results of this study showed that UWEPs play an important role in the household livelihood diversification, and these results are summarized below:

\section{Diversity of uses.}

UWEPs offer various uses such as fuel wood, fencing, construction, medicinal, fodder, timber, honey production and detergent (Figure 3). More than three-fourths of UWEPs in the study sites are used for fuel wood and fencing purposes. The community utilized these plants for various reasons (Table 9). About $56 \%$ and $33.3 \%$ of the respondents in MLA mentioned that UWEPs were used to supplement their staple foods and for refreshment, respectively. Also $21 \%$ of the respondents consume products to fill food gaps. In the LLA, $67 \%$ of the respondents mentioned that UWEPs were used in

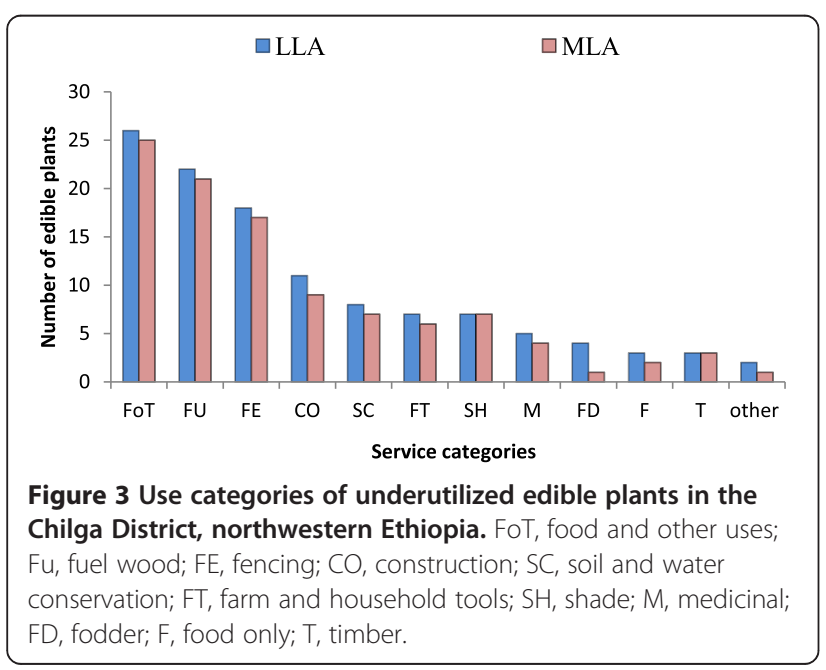

times of normal diet. UWEP utilization by wealth class using the free-list exercise approach is shown in Table 10.

UWEP citation in the poor HHs was significantly higher $(P<0.05)$ than for medium and rich wealth classes in the Walideba and Chalia Debire kebeles. Similarly, UWEP citation in the poor HHs was significantly higher than for the richest groups in Quavier Lomiye Kebele. Plant citation in Tenbera Kebele was significantly different among wealth classes in the following order: poor $>$ medium $>$ rich.

2. Income generating role of underutilized wild edible plants.

UWEPs could generate income for HHs through either sales to domestic market or exporting to neighboring countries, mainly the Sudan (Table 11). Twelve marketable UWEPs were recorded with the mean unit price of products ranging from 0.63 to 5.6 ETB (Ethiopian Birr). Youngsters in the local market sell most of these marketable UWEPs (eight plants). Of the marketable UWEPs, Tamarindus indica and Hibiscus cannabinus were the most highly priced species. About $83 \%$ and $17 \%$ of the marketable UWEPs are marketed in the local markets and for export, respectively (Figure 4a). Of all marketable UWEPs, fruits represent the highest proportion of edible parts (about 75\%) (Figure $4 \mathrm{~b}$ ).

3. Direct matrix ranking for underutilized wild edible plants.

Seven UWEP species in the LLA and five in the MLA were selected, and direct matrix ranking was conducted based on the key informants' preferences of use category. Thus, food and fuel use categories were the first and second ranked categories, respectively, for the selected multipurpose species (Table 12) for lowland and (Table 13) for MLA. When overall categories were considered, species with top score ranking were ordered as follows: 
Table 9 Consumption roles of underutilized wild edible plants in the study area, northwestern Ethiopia

\begin{tabular}{|c|c|c|c|c|c|c|c|c|}
\hline \multirow[t]{2}{*}{ Agroecology } & \multicolumn{2}{|c|}{ Supplemental } & \multicolumn{2}{|l|}{ Recreational } & \multicolumn{2}{|c|}{ Fill food gaps } & \multicolumn{2}{|l|}{ All } \\
\hline & Informants & $\%$ & Informants & $\%$ & Informants & $\%$ & Informants & $\%$ \\
\hline$\overline{M L A}$ & 27 & 56.3 & 16 & 33.3 & 10 & 20.8 & 10 & 20.8 \\
\hline LLA & 32 & 66.7 & 14 & 29.2 & 6 & 12.5 & 11 & 22.9 \\
\hline
\end{tabular}

LLA, lowland agroecology; MLA, midland agroecology.

Diospyros mespiliformis $>$ Syzygium guineense $>$ Tamarindus indica for LLA; Syzygium guineens $>$ Diospyros abysinica > Ximenia americana for MLA. Carisa spinarum received the list score from both agroecologies.

Informant consensus and preference of underutilized wild edible plants

Species preference ranking of UWEPs was conducted based on the informants' consensus approach to find out the relative importance of plants to the local community (Table 14). The most preferred species in decreasing order were S. guineense, D. abyssinica, Carissa spinarum, Mimusops kummel, D. mesiliformis, Ximenia americana and Cordia africana. However, species preference varies from kebele to kebele. S. guineense, D. mespiliformis and M. kummel were the most preferred edible plants, cited by $95.8 \%$ of respondents in Walideba Kebele. Similarly, S. guineense and M. kummel were the best species cited by all respondents in Chalia Debire Kebele. Again, $D$. mesiliformis was the preferred species in Quavier Lomiye and Tenbera kebeles (species cited by $\geq 29$ informants of the total respondents).

Selection and ranking of the most preferred candidate UWEPs, based on their taste and use, was conducted in each kebele. S. guineense is the most preferred species in Walideba and Chalia Debire kebeles (Figure 5 a and b), while Saba comorensis was the most preferred in Quavier Lomiye and Tenebera (Figure $5 \mathrm{c}$ and d). In terms of conservation demand of species, $M$. kummel and X. americana were the most highly preferred ones in the MLA and LLA study sites, respectively.

\section{Underutilized wild edible plant list exercise}

With regard to list length for free plants, variation exists between age groups. Respondents younger than 40 years of age cited more UWEPs than older people did across the study kebeles (Figure 6a). The Spearman correlation test has also shown a significant negative correlation between age and UWEPs list $(\mathrm{r}=-0.326, P<0.05)$.

The local community gains knowledge about UWEPs utilization, processing and management through experience (Figure 6b). However, the major acquisition/transfer method was from parents, friends and relatives, and neighbors in both agroecologies. Sources of knowledge or acquisitions for the majority of respondents (87.5\%) in MLA and $73 \%$ in LLA were the parents.

\section{Traditional management practices and threats of underutilized edible plants}

The results of this study indicated that there was a lack of training to local community to improve management, conservation and utilization of UWEPs (Table 15). More than $77 \%$ of the respondents in MLA and $87.5 \%$ in LLA indicated that training on conservation and utilization of UWEPs was not given from any concerned body. This indicated that the local community utilizes, manages and conserves these plant resources only through experience and traditional knowledge.

Identification and preference ranking of the major threats of UWEPs based on their destructive effects were conducted (Table 16). It confirmed that illegal charcoal production, fuel wood collection, construction, agricultural land expansion, overgrazing and fire were the dominant threats.

Local communities practice different traditional management, which includes planting around the home garden, pruning, pollarding, fencing, and preventing growth of the most important plants by local culture in both the LLA and MLA (Table 16). Of the management practices; fencing, pollarding and local culture are the dominant practices in the LLA. In similar fashion, planting around

Table 10 Mean ( \pm std) of underutilized wild edible plants free-list exercise by wealth class in the study sites, northwestern Ethiopia

\begin{tabular}{|c|c|c|c|c|}
\hline Wealth category & Walideba (Mean \pm std) & Chalia Debire (Mean \pm std) & Quavier Lomiye (Mean \pm std) & Tenbera (Mean \pm std) \\
\hline Poor $(n=32)$ & $15.50^{a} \pm 2.14$ & $14.25^{a} \pm 0.65$ & $12.38^{a} \pm 1.19$ & $14.13^{a} \pm 0.81$ \\
\hline Medium $(n=32)$ & $9.75^{b} \pm 0.70$ & $9.75^{b} \pm 0.26$ & $10.13^{\mathrm{ab}} \pm 0.92$ & $9.63^{b} \pm 0.73$ \\
\hline Rich $(n=32)$ & $7.75^{b} \pm 0.82$ & $9.75^{b} \pm 0.80$ & $8.25^{b} \pm 0.88$ & $6.63^{c} \pm 0.98$ \\
\hline Over All (96) & $11.00 \pm 1.03$ & $11.25 \pm 0.68$ & $10.25 \pm 0.66$ & $10.13 \pm 0.81$ \\
\hline
\end{tabular}

$\overline{\mathrm{a}, \mathrm{b}}$ Means with different letters ordered vertically in each Kebele were significant $(P<0.05)$. 
Table 11 List of marketable underutilized wild edible plants in the Chilga District, northwestern Ethiopia

\begin{tabular}{|c|c|c|c|c|c|c|c|}
\hline Species name & Parts marketed & Unit & Mean price $^{a}$ & Number of respondents & Seller group ${ }^{b}$ & Market category & Rank \\
\hline Carisa spinarum & $\mathrm{F}$ & cup & 0.83 & 6 & younger & D & 10 \\
\hline Corchorus olitorius & L & handful & 2.2 & 10 & all & $\mathrm{D}$ & 8 \\
\hline Diospryos mesiliformis & $\mathrm{F}$ & cup & 0.91 & 46 & younger & D & 2 \\
\hline Diospyros abyssinica & $\mathrm{F}$ & cup & 0.8 & 27 & younger's & $\mathrm{D}$ & 6 \\
\hline Ficus sur & $\mathrm{F}$ & cup & 0.63 & 2 & younger & D & 12 \\
\hline Hibiscus cannabinus & Se & cup & 4.33 & 3 & adult & Exp & 11 \\
\hline Mimusops Kummel & $\mathrm{F}$ & cup & 1 & 45 & younger & D & 3 \\
\hline Saba comorensis & $\mathrm{F}$ & number & 0.7 & 35 & all & $\mathrm{D}$ & 4 \\
\hline Syzygium guineense & $\mathrm{F}$ & cup & 1 & 64 & younger's & D & 1 \\
\hline Tamarindus indica & Se & $\mathrm{kg}$ & 5.6 & 21 & all & Exp & 7 \\
\hline Ximenia Americana & $\mathrm{F}$ & cup & 0.95 & 33 & younger & D & 5 \\
\hline Ziziphus spina-christi & $\mathrm{F}$ & cup & 0.7 & 9 & younger & D & 9 \\
\hline
\end{tabular}

F, fruit; Se, seed; L, leaf; L, local market; Exp, exported to other countries; a, Ethiopian birr (ETB); b, local classification of below 18-years old as younger and from 18- to 30 -years of age as adult; Ranks were given by number of respondents.

home gardens and backyards and pollarding were the major practices in the MLA.

Fuel wood and illegal charcoal production and construction were the main threats in the MLA, whereas agricultural expansion, fuel wood collection, and charcoal making were dominant threats in the LLA.

\section{Discussion}

\section{Importance value index}

The importance value index (IVI) of all woody species indicates the ecological importance of each species to the area. In addition, it indicates the types of plant species on which the rural community is more reliant. The four top ranked species according to IVI value (A. leiocarrpa, S. guineense, F. sycomorus and D. abyssinica) in the whole area were the most important UWEPs. The high IVI of these species is probably due to their ability to produce a high number of seeds and maintain a persistent soil seed bank. There was variation in IVI in agroecology and land uses, probably due to variation of species adaptation to different agroecologies and human disturbance [33]. Thus, high IVI confirmed the potential of these species to adapt to an area and to resist anthropogenic disturbance [33].

\section{Floristic composition, distribution and diversity of underutilized edible plants}

A good number of UWEPs (33 species) were recorded compared to other areas in the Amhara region [8]. These UWEPs include trees, shrubs and herbs. Most UWEPs were also documented elsewhere in Ethiopia; for instance, seven species are found in the semi-arid lowlands of southern Ethiopia [3,7], species in Derashe and Kucha, southern Ethiopia $[7,20]$, species in Amhara region, northern Ethiopia (8); 20 species in northern Ethiopia; eight species in southeastern Ethiopia; five species in eastern Ethiopia; six species in southeastern Ethiopia [10]. The existence of these plants in different regions of the country indicates their ecological adaptation over a large geographical area and their edibility by different ethnic groups.

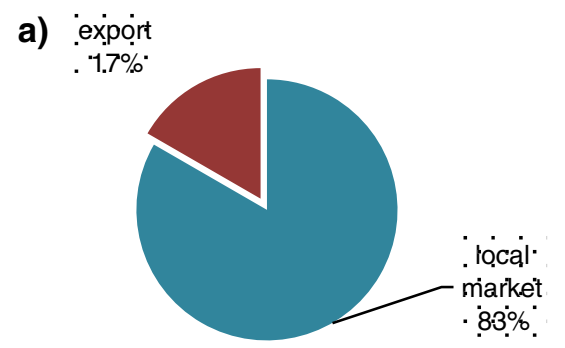

Market category of marketable edible plants

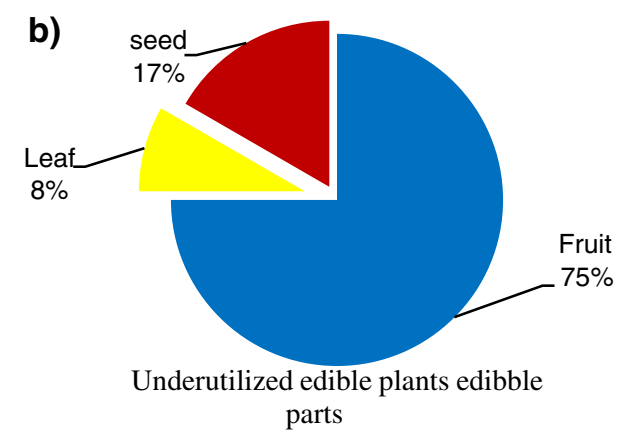

Figure 4 Market categories of marketable edible plants (a) and parts sold (b) in the Chilga District, northwestern Ethiopia. 
Table 12 Direct matrix average score of seven underutilized edible plants in lowland agroecology (LLA) in northwestern Ethiopia

\begin{tabular}{|c|c|c|c|c|c|c|c|c|c|c|}
\hline \multirow[b]{2}{*}{ Species } & \multicolumn{8}{|c|}{ Use category } & \multirow[b]{2}{*}{ Total } & \multirow[b]{2}{*}{ Rank } \\
\hline & Food & Fuel wood & Fencing & Constru-ction & Shade & Medicinal & Home and farm tools & Timber & & \\
\hline Diospyros mespiliformis & 5 & 3 & 2 & 4 & 3 & 0 & 2 & 2 & 20 & 1 \\
\hline Syzygium guineense & 5 & 4 & 2 & 2 & 2 & 1 & 0 & 1 & 17 & 2 \\
\hline Tamarindus indica & 5 & 4 & 2 & 2 & 2 & 0 & 2 & 1 & 17 & 2 \\
\hline Diospyros abyssinica & 5 & 4 & 2 & 3 & 1 & 0 & 1 & 1 & 16 & 3 \\
\hline Ziziphus spina-christii & 4 & 3 & 4 & 2 & 1 & 1 & 1 & 1 & 16 & 3 \\
\hline Ximenia Americana & 5 & 4 & 3 & 0 & 0 & 2 & 2 & 0 & 15 & 4 \\
\hline Carisa spinarum & 4 & 2 & 2 & 0 & 0 & 5 & 1 & 0 & 15 & 4 \\
\hline Total & 33 & 24 & 18 & 13 & 9 & 8 & 7 & 5 & & \\
\hline Rank & 1 & 2 & 3 & 4 & 5 & 6 & 7 & 8 & & \\
\hline
\end{tabular}

Natural forests, riverine areas and farmlands were centers for UWEPs in the study sites in both MLA and LLA. Similar to this study UWEPs in other parts of Ethiopia were concentrated in farmlands, riverine areas and natural forests $[7,8,10,33]$. Forests of the world provide livelihoods and food for 300 million people in the form of non-timber forest products [34]. Again, their distributions in different agroecologies vary due to differences in species' physiological adaptations [7].

The study shows almost the same species richness among land uses. As Fentahun and Hager [8] explained, the species richness of wild edible plants is affected by altitude, personal preference and selective management of trees by farmers, especially for those found on farmlands. The Shannon diversity of land uses in both agroecologies is greater than 1.5. Thus, high diversity exists in both agroecologies. Significant differences among kebeles might be due to variation in the levels of human disturbance.

\section{Utilization and socioeconomic implication}

Trees, followed by shrubs, were the dominant growth forms of UWEPs in the study area. Although relatively small in number, herbaceous plants were also consumed. The report by Fentahun and Hager [8] in the Amhara region and in Tilahun and Mirutse [9] in the lower river valley of Debub Omo Zone was consistent with the present finding that trees were the leading growth forms. In contrast, Ermias et al. [13] indicated that shrubs were the dominant growth forms in Ethiopia, followed by trees, herbs and climbers. Fruits were the commonly utilized edible parts in the study area. In agreement with this finding, Ermias et al. [13] and Getachew et al. [35] found fruits as the widely used parts.

The results of this study indicate that UWEPs are used mainly to supplement staple food, to fill food gaps and for refreshment purposes. In agreement with the present study, other findings elsewhere $[5,36,37]$ indicate their supplemental role. The greater number of plant citations by the poorest community in the study area indicates the consumption level and familiarity of the community with these plants. Seasonal food shortages, when household stocks were empty and the new crop was still in the field, were common times to focus on collecting, selling and consuming underutilized edible

Table 13 Direct matrix average score of five underutilized edible plants in midland agroecology (MLA) in northwestern Ethiopia

\begin{tabular}{|c|c|c|c|c|c|c|c|}
\hline Use category & Syzygium guineense & Diospyros abyssinica & Ximenia americana & Mimusops kummel & Carissa spinarum & Total & Rank \\
\hline Food & 5 & 4 & 5 & 5 & 4 & 23 & 1 \\
\hline Fuel 2ood & 4 & 4 & 4 & 4 & 3 & 18 & 2 \\
\hline Construction & 3 & 4 & 3 & 3 & 0 & 12 & 3 \\
\hline Fencing & 2 & 3 & 2 & 2 & 2 & 11 & 4 \\
\hline Shade & 2 & 2 & 2 & 2 & 0 & 9 & 5 \\
\hline Medicinal & 1 & 0 & 0 & 0 & 5 & 6 & 6 \\
\hline Home and Farm Tools & 0 & 1 & 1 & 1 & 1 & 3 & 7 \\
\hline Timber & 0 & 0 & 0 & 0 & 0 & 0 & 8 \\
\hline Total & 17 & 17 & 16 & 16 & 14 & & \\
\hline Rank & 1 & 1 & 2 & 2 & 3 & & \\
\hline
\end{tabular}


Table 14 List of frequently cited edible plants in the study sites, northwestern Ethiopia

\begin{tabular}{|c|c|c|c|c|c|}
\hline Edible species & Walideba & Chalia Debire & Quavier Lomiye & Tenbera & Total \\
\hline Syzygium guineense & 23 & 24 & 16 & 17 & 80 \\
\hline Carissa spinarum & 20 & 20 & 19 & 17 & 76 \\
\hline Diospyros abyssinica & 22 & 19 & 15 & 17 & 73 \\
\hline Diospyros mespiliformis & 23 & 2 & 24 & 21 & 70 \\
\hline Ximenia Americana & 11 & 21 & 18 & 18 & 68 \\
\hline Mimusops kummel & 23 & 24 & 8 & 12 & 67 \\
\hline Cordia africana & 19 & 22 & 7 & 15 & 63 \\
\hline Ficus sycomorus & 12 & 13 & 17 & 11 & 53 \\
\hline Saba comorensis & 2 & 14 & 22 & 14 & 52 \\
\hline Ficus sur & 17 & 16 & 6 & 12 & 51 \\
\hline Balanites aegyptiaca & 16 & 2 & 8 & 17 & 43 \\
\hline Dioscorea prahensilis & 5 & 20 & 7 & 9 & 41 \\
\hline Ziziphus spina-christi & 6 & 1 & 19 & 11 & 37 \\
\hline Tamarindus indica & 0 & 0 & 19 & 10 & 29 \\
\hline
\end{tabular}

plants [36,38]. Marginalized and poor communities are more vulnerable to drought, and thus, are more dependent on these plants $[13,34,38,39]$.

The rural communities of this study, especially the lowland kebeles, preferred Corchorus olitorius more than other vegetables because they believe it has more nutritional value. Debela et al. [5] also reports on the nutritional richness of this plant. Thus, local people in the study area bypass nutritional insecurity by consuming UWEPs. Some species that were preferable in the study area (for example, T. indica, S. comorensis and C. spinarum) are also priority ranked species in Kenya [40].

Once more, most of UWEPs provide service in addition to food value. Different researchers elsewhere in Ethiopia have also noted multiple uses for UWEPs such as preparation of remedies, fuel wood, fencing, construction

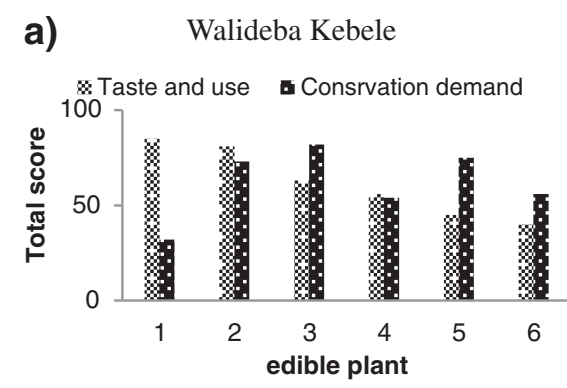

c) Quavier Lomiye Kebele

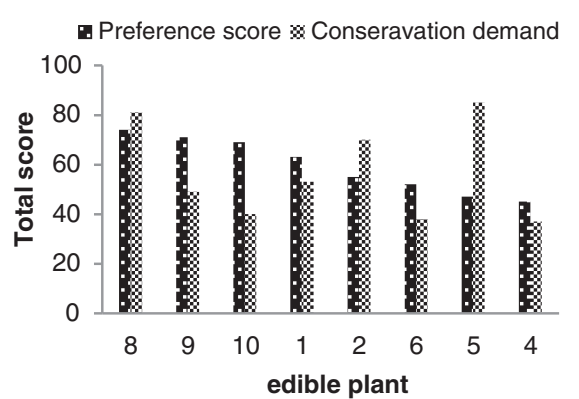

b) Chalia Debire Keble

- Taste and use score $\alpha$ Conservation demand score

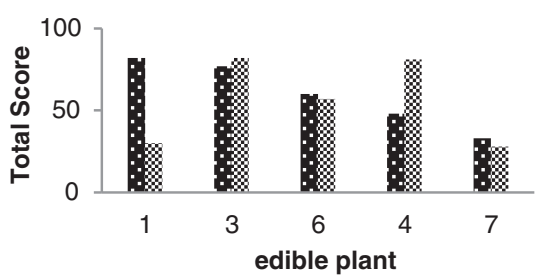

d)

Tenbera Keble

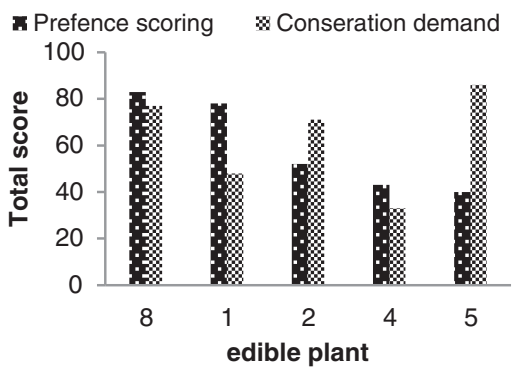

Figure 5 Preference ranking of edible plants in the study sites in the Chilga district, northwestern Ethiopia. Legend: $1=$ Syzygium guineense; 2 = Diospryos melisformis; 3 = Mimusops kummel; 4 = Diospyros abyssinica; 5 =Ximenia americana; $6=$ Carissa spinarum; $7=$ Cordia Africana; $8=$ Saba comorensis; 9 = Corchorus olitorius; $10=$ Tamarindus indica. 


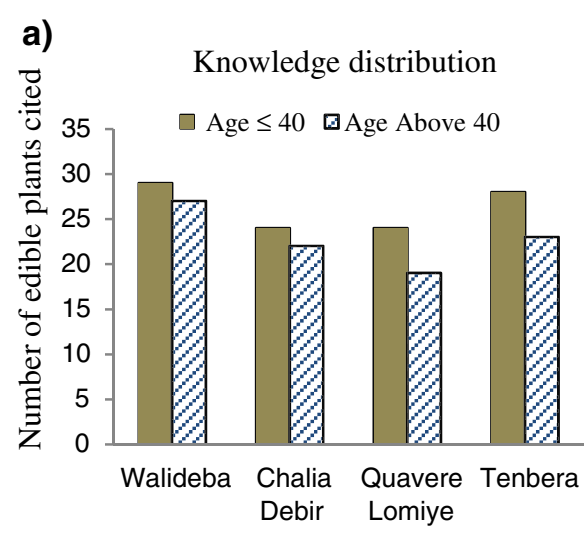

Study Kebeles b) Knowledge Aquisition method

๑MLA (48) Informant $\quad$ LLA (48) Informant

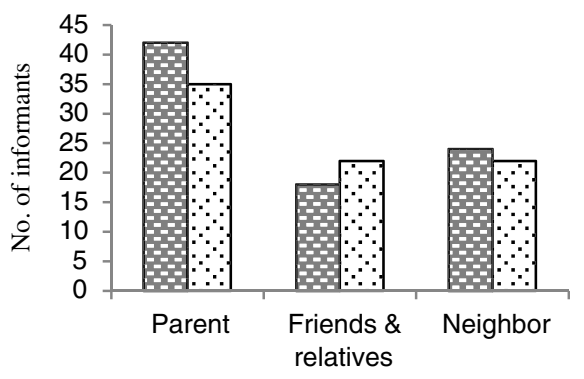

Acquisition method

Figure 6 Knowledge distribution and acquisition methods of edible plant in the Chilga District, northwestern Ethiopia.

and timber, farm and household implements and livestock fodder [7-9]. Marketable wild edible plants such as $X$. americana, S. guineense, T. indica, C. spinarum and $M$. kummel also create household income opportunities. A few income-generating species like $S$. guineense, T. indica, C. spinarum and M. kummel were also reported in other areas $[7,8]$. Furthermore, income is gained from selling other parts such as stems and branches [3,7]. C. Africana, for instance, one of the most widely used edible plants in the study area, is preferred for timber production.

According to Bharucha and Pretty [34], there is no comprehensive global estimate of the economic value of UWEPs; therefore, quantitative analyses face methodological difficulties. For most studies, use of different valuation methods and diversity scales are rarely equivalent. Second, the sale of products is often illegal and therefore under-reported. This was observed in the study areas where various UWEPs plants sold at local market and even exported to Sudan were not valued correctly.

\section{Knowledge distribution of underutilized edible plants}

Ethnobotanical knowledge and practice within any culture varies depending on such factors as cultural attributes. In a free-list exercise, the differences in list length and content are measures of intraspecific cultural variation [41]. Younger respondents cited a higher number of UWEPs than elders in each study site. Fentahun and

Table 15 Response of households on training gained about conservation and utilization of underutilized edible plants in the Chilga District, northwestern Ethiopia

\begin{tabular}{lllll}
\hline Response & $\begin{array}{l}\text { MLA }(\mathbf{n}=\mathbf{4 8}) \\
\text { Informants }\end{array}$ & $\begin{array}{l}\text { LLA }(\mathbf{n}=\mathbf{4 8}) \\
\text { \% }\end{array}$ & Informants & \% \\
\hline Yes & 11 & 22.9 & 6 & 12.5 \\
No & 37 & 77.1 & 42 & 87.5 \\
Total & 48 & 100 & 48 & 100 \\
\hline
\end{tabular}

Hager [8] also reported similar results, as younger respondents cited higher numbers than elders did. This might be because of the variation of informant's consumption preferences between adults and youngsters. Adults avoid eating most UWEPs because consumption of wild food plants is seen as a sign of poverty [42]. As a result, their list might be limited to only those species that they are accustomed to eating rather than what they know to be edible. The knowledge acquisition methods (parents are the major source) also proved the ignorance of some species by adults. In addition, younger people had an intimate association with plants in their day-today lives and had more experience with collection than the older people $[8,43]$. A lack of modern training in the study area is also an indicator of the acquisition of knowledge by experience and the effect of their interaction with plants in their daily life.

Table 16 Traditional management practices and threats of underutilized edible plants in the Chilga District, northwestern Ethiopia

\begin{tabular}{llllll}
\hline Csl & \multicolumn{2}{l}{ LLA (48) } & & & MLA (48) \\
\cline { 2 - 3 } Management practices & Informants & $\%$ & & Informants & $\%$ \\
\hline Planting around home garden & 9 & 18.8 & 18 & 37.5 \\
Pruning & 8 & 16.7 & 9 & 18.8 \\
Pollarding & 10 & 20.8 & 14 & 29.2 \\
Fencing & 10 & 20.8 & 11 & 22.9 \\
Protected by culture & 12 & 25 & 11 & 22.9 \\
Threats & & & & & \\
Agricultural expansion & 32 & 66.7 & 21 & 43.8 \\
Construction & 26 & 54.2 & 37 & 77.1 \\
Fuel wood collection and & 32 & 66.7 & 40 & 83.3 \\
charcoal making & & & & \\
Overgrazing & 23 & 47.9 & 19 & 39.6 \\
Fire & 11 & 22.9 & 0 & 0 \\
\hline
\end{tabular}




\section{Management practices and threats to underutilized edible plants}

The farmers in the study area apply some management activities like pruning and pollarding for UWEPs in farmland use. In addition, the farmers plant some plants in their front yards and backyards. However, compared to other cultivated plants, the management practices were very small. The study by Fentahu and Hager [8] in other semi-arid areas of the Amhara region similarly depicted a lower level of management, and if any, limited to lopping and pollarding.

The threats to UWEPs in the study area are similar to threats that affect nonedible wild plants. Agricultural expansion, overgrazing, fire and other utilization-related factors such as fuel wood and charcoal, construction, and house and farm implements are the major threats in both agroecologies. Different researchers have documented these threats $[3,7,13,38]$ to UWEPs. Furthermore, UWEPs are collected in natural environments, which are subjected to less management and exposed to anthropogenic threats [13].

\section{Conclusions and recommendations}

The Chilga District, located in the Amhara region, northwestern Ethiopia is endowed with diverse UWEPs and ethnobotanical knowledge. Thirty-three UWEPs (22 families) were recorded. These plants are distributed in natural forests, riverine forests and farmlands.

UWEPs are consumed for supplementing staple food, filling food gaps and recreational value. This utilization is significant in the poorest communities. Most of the encountered UWEPs provide other services including medicinal value, fuel wood and charcoal, construction, timber, and farm and household implements, thereby generating income from the sale of the products and their parts. Thus, UWEPs are the solution to diversification of rural household livelihoods. The utilization of some UWEPs (such as S. guineense, D. abyssinica, C. spinarum, M. kummel, D. mesiliformis, X. americana and C. africana) is more popular than for others.

UWEPs are suffering from the threats of agricultural expansion, overharvesting (for fuel wood, construction, and fencing) and overgrazing in both agroecologies. However, the management activities are also lower.

The local community utilizes UWEPs without gaining organized training, which is a threat to the sustainability of these plants. Thus, provision of training from the district, zonal offices, and NGOs for different management activities and the application of this training to projects that seek to maximize the value of UWEPs to local community are needed. This study focuses on diversity, role, threats and associated plant-use knowledge. Further study on the nutritional analysis and economic valuation of UWEPs is needed.

\section{Additional file}

Additional file 1: Importance value index of plants.

\section{Abbreviations}

FL: farmland; HH: household; IVA: importance value index; KA: kebele; KI: key informants; LLA: lowland agroecology; LSd: least significance difference; m.a. s.l: meters above sea level; MLA: midland agroecology; NF: natural Forest; R: riverine forest; UWEP: underutilized wild edible woody plant.

\section{Competing interests}

The authors declare that they have no competing interests.

\section{Authors' contributions}

MT: conception and design, data collection and analysis, manuscript writing and final approval of the manuscript. ZA: data analysis, critical revision and final approval of the manuscript. SZ: critical revision and final approval of the manuscript. All authors read and approved the final manuscript.

\section{Acknowledgements}

We thank to the Development Partnership in higher Education, Department for International development, (DeLPHE) for financial support of this research, which otherwise would have faced financial constraints. We are also thankful to the traditional healers and local people of Chilga District who generously shared their knowledge on underutilized edible plants. The Environmental Protection office and Agricultural office of Chilga District are also acknowledged for their provision of various basic data and support

\section{Author details}

'Department of Natural Resource Management, University of Gondar, P.O. Box 196, Gondar, Ethiopia. ${ }^{2}$ School of Forestry, Wondo Genet College of Forestry and Natural Resources, Hawassa University, P.O. Box 128,

Shashemene, Hawassa, Ethiopia. ${ }^{3}$ Department of Biology, Addis Ababa Science and Technology University, Addis Ababa, Ethiopia.

Received: 3 February 2014 Accepted: 8 August 2014

Published: 27 August 2014

\section{References}

1. Magbagbeola JA, Adetoso JA, Owolabi OA: Neglected and underutilized species (NUS): panacea for community focused development to poverty alleviation/poverty reduction in Nigeria. J Econ Int/ Finance 2010, 2:208-211

2. Jaenicke H, Hoschele-Zeledon I: Strategic Framework for Underutilized Plant Species Research and Development, with Special Reference to Asia and the Pacific, and to Sub-Saharan Africa. Rome, Italy: International Centre for Underutilized Crops, Colombo, Sri Lanka and Global Facilitation Unit for Underutilized Species; 2006

3. Assefa A, Abebe T: Wild edible trees and shrubs in the semi-arid lowlands of southern Ethiopia. J Sci Dev 2011, 1:5-19.

4. Van Andel T: Non-timber forest products the value of wild plants. Wageningen: Agrodok 39, Agromisa Foundation and CTA; 2006

5. Hunde D, Njoka J, Zemede A, Nyangito M: Wild edible fruits of importance for human nutrition in semiarid parts of east shewa zone, Ethiopia: associated indigenous knowledge and implications to food security. Pak J Nutr 2011, 10:40-50.

6. IBC (Institute of Biodiversity Conservation): Ethiopia: Second Country Report on the State of Plant Genetic Resources for Food and Agriculture (PGRFA) to FAO. Addis Ababa, Ethiopia: 2007

7. Kebu B, Fassil K: Ethnobotanical study of wild edible plants in derashe and kucha districts, south Ethiopia. J Ethnobiol Ethnomed 2006, 2:53.

8. Fentahun $\mathrm{M}, \mathrm{Hager} \mathrm{H}$ : Wild edible fruit species cultural domain, informant species competence and preference in three districts of amhara region, Ethiopia. Ethnobotany Research \& Applications 2008, 6:487-502.

9. Tilahun T, Mirutse G: Ethinobotanical study of wild edible plants of Kara and kwego semi-pastoralist people in lower Omo river valley, debub Omo zone, SNNPR, Ethiopia. J Ethnobiol Ethnomed 2010, 6:23.

10. Demel T, Abeje E: Status of indigenous fruits in Ethiopia. Review and Appraisal on the Status of Indigenous Fruits in Eastern Africa. In A 
synthesis report for IPGRI-SAFORGEN. Edited by Chikamai B, Eyog-Matig O. Kweka: 2004.

11. MoARD: Horn of Africa Consultations of Food Security, Country Report. Addis Ababa, Ethiopia: Ministry of Agriculture and Rural Development, Government of Ethiopia; 2007.

12. Sabates-Wheeler R, Tefera M, Bekele G: Future-Agricultures, Working Paper 044. Ethiopia: Future-Agricultures, Working Paper 044; 2012:43.

13. Lulekal E, Asfaw Z, Kelbessa E, Van Damme P: Wild edible plants in Ethiopia: a review on their potential to combat food insecurity. Afrika Focus 2011, 24:71-121.

14. CDOA (Chilga District Office of Agricultural): Chilga District Agricultural Office 2012 Annual Report. Aykel, Ethiopia: 2012.

15. Bernard HR: Research Methods in Anthropology: Qualitative and quantitative Approaches. Walnut Creek CA: Altamira; 2002.

16. Cotton CM: Ethnobotany: Principles and Applications. Chichester, England: John Wiley and Sons Ltd; 1996.

17. Martin GJ: Ethnobotany: A Methods Manual. London, UK: Chapman and Hall; 1995.

18. Jain A, Sundriyal M, Roshnibala S, Kotoky R, Kanjilal PB, Singh HB, Sundriyal $\mathrm{RC}$ : Dietary use and conservation concern of edible wetland plants at indo-Burma hotspot: a case study from northeast India. J Ethnobiol Ethnomed 2011, 7:29

19. Hedberg I, Edwards S: Pittosoraceae to Araliaceae. In Flora of Ethiopia and Eritrea Vol. 3. Addis Ababa and Uppsala, Sweden: The National Herbarium Addis Ababa University; 1989:659.

20. Edwards S, Mesfin T, Hedberg I: Canellaceae to Euphorbiaceae. In Flora of Ethiopia and Eritrea Vol. 2 Part 2. Ethiopia and Upsala, Sweden: The National Herbarium Addis Ababa; 1995:456.

21. Edwards S, Sebsebe D, Hedberg I: Hydrocharitaceae to Arecaceae. In Flora of Ethiopia and Eritrea, Volume 6. Edited by Edwards S, Sebsebe D, Hedberg I. Addis Ababa and Uppsala: The National Herbarium; 1997:586.

22. Edwards S, Mesfin T, Sebsebe D, Hedberg I: Magnoliaceae to Flacourtiaceae. In Flora of Ethiopia and Eritrea Vol. 2 Part 1. Ethiopia and Upsala, Sweden: The National Herbarium Addis Ababa; 2000:532.

23. Mesfin T: Asteraceae. In Flora of Ethiopia and Eritrea Vol. 4, Part 2. Edited by Hedberg I, Friis I, Edwards S. Addis Ababa and Uppsala: The National Herbarium; 2004:408.

24. Hedberg I, Ensermu K, Edwards S, Sebessebe D, Persson E: Plantaginaceae. In Flora of Ethiopia and Eritrea, Volume 5. Edited by Hedberg I, Ensermu K, Edwards S, Sebessebe D, Persson E. Addis Ababa and Uppsala: The National Herbarium; 2006:690.

25. Hedberg I, Friis I, Person E: General Part and Index to Vol 1-7. Flora of Ethiopia and Eritrea Volume 8. Addis Ababa, Ethiopia and Uppsala, Sweden: The National Herbarium; 2009.

26. Stohlgren TJ, Falkner MB, Schell LD: A modified Whittaker nested vegetation sampling method vegetation. J. Vegetatio 1995, 117:113-121.

27. Hoft M, Barik SK, Lykke AM: Quantitative Ethnobotany. Applications of Multivariate and Statistical Analyses in Ethnobotany. People and Plants working paper 6. Paris: UNESCO; 1999.

28. Clarke KR, Warwick RM: Changes in Marine Communities: An Approach to Statistical Analysis and Interpretation, Primer-E. 2nd edition. Plymouth: Springer verlag; 2001.

29. Maguran A: Measuring Biological Diversity. London: Blackwell science LtD, a Blackwell publishing company; 2004.

30. Pielou EC: The measurement of diversity in different types of biological collections. J Theoret Biol 1966, 13:131-144.

31. Kent M, Coker P: Vegetation Description and Analysis: A practical approach. London: Belhaven Press; 1992.

32. Jha PK: Environment plant resources and quantities estimation methods for vegetation analysis. In Ethnobotany for Conservation and Community Development. Edited by Shrestha KK, Jha PK, Shengi P, Rastogi A, Rajbandary S, Joshi M. Nepal: Ethnobotanical Society of Nepal (ESO); 1997.

33. Adefires W: Population Status and Socio-economic Importance of Gum and Resin Bearing Species in Borana Lowlands, Southern Ethiopia, M.Sc. Thesis. Addis Ababa, Ethiopia: Addis Ababa University; 2006.

34. Bharucha Z, Pretty J: The roles and values of wild foods in agricultural systems. Philoss Trans Royal Soc B 2010, 365:2913-2926.

35. Addis G, Urga K, Dikasso D: Ethnobotanical study of edible wild plants in some selected districts of Ethiopia. J Human Ecol 2005, 33:83-118.

36. Fentahun M, Hager H: Exploiting locally available resources for food and nutritional security enhancement: wild fruits diversity, potential and state of exploitation in the amhara region of Ethiopia. J Food Sci 2009, 1:207-219.

37. Hunde D, Njoka J, Zemede A, Nyangito MM: Seasonal availability and consumption of wild edible plants in semiarid Ethiopia: implications to food security and climate change adaptation. J Hort For 2010, 3:138-149.

38. Guinand Y, Dechassa Lemessa D: Wild food plants in Southern Ethiopia: Reflections on the role of 'famine foods' at a time of drought. Addis Ababa, Ethiopia: UNDP-EUE Field Mission Report; 2000.

39. Asfaw Z: The future of wild food plants in southern Ethiopia: ecosystem conservation coupled with enhancement of the roles of key social groups. Acta Hortic 2009, 806:701-707.

40. Pauline M, Linus W: Status of Indigenous Fruits in Kenya. Review and Appraisal on the Status of Indigenous Fruits in Eastern Africa. In A Synthesis Report for IPGRI-SAFORGEN. FORNESSA-AFREA Logo; 2004.

41. Quailan R: Consideration for collecting freelists in the field. Examples in ethnobotany. Field Methods, 17:1-16.

42. Garcia GSC: The mother - child nexus: knowledge and valuation of wild food plants in Wayanad, Western Ghats. India J Ethnobiol Ethnomed 2006, 2:39.

43. Al-Qura'n SA: Ethnobotanical and ecological studies of wild edible plants in Jordan. Libyan Agric Res Cent J Int 2010, 1:231-243.

doi:10.1186/2048-7010-3-12

Cite this article as: Tebkew et al.: Underutilized wild edible plants in the Chilga District, northwestern Ethiopia: focus on wild woody plants. Agriculture \& Food Security 2014 3:12

\section{Submit your next manuscript to BioMed Central and take full advantage of:}

- Convenient online submission

- Thorough peer review

- No space constraints or color figure charges

- Immediate publication on acceptance

- Inclusion in PubMed, CAS, Scopus and Google Scholar

- Research which is freely available for redistribution

Submit your manuscript at www.biomedcentral.com/submit
C Biomed Central 